\title{
Legal regulation of environmental protection, management of natural resources, and environmental safety in construction sector
}

\author{
Elena Voskresenskaya ${ }^{1, *}$, Lybov Vorona-Slivinskaya ${ }^{2}$ and Sergey Panov $^{2}$ \\ ${ }^{1}$ Peter the Great St.Petersburg Polytechnic University, 195251, Polytechnicheskaya str., 29, St. \\ Petersburg, Russia \\ ${ }^{2}$ Saint Petersburg State University of Architecture and Civil Engineering, 2nd Krasnoarmeyskaya St., \\ 4, 190005, St. Petersburg, Russia
}

\begin{abstract}
The current state of the environment in general, including the construction sector, is experiencing an excessive technogenic impact. Therefore, the authors consider the process of ecologization as an important condition for ensuring the sustainability of the development of construction production. The paper concludes that innovative approaches in the development and implementation of environmental protection programs for construction based on fundamentally new methods of natural resource use, resource saving, transition to new technologies for the production of building materials and structures determine the main directions for improving technological and other processes in this area. The authors determined that the increase in the efficiency of environmental measures in construction sector depends mainly on the location of construction sites and the specific feature of this production. In this regard, at each level of the construction process, there is a danger of pollution of the natural environment, which entails negative consequences of anthropogenic nature. Developing and introducing organizational and economic methods of innovative nature protection activities into the construction production aimed at improving the environmental safety of construction process and upgrading the quality of the surrounding environment on adjacent territories to construction sites is an urgent task.
\end{abstract}

\section{Introduction}

The conditions that defined the necessity of studying this topic are the need to elaborate improved methods for the legal and organizational and economic mechanism of rational nature management and environmental protection in construction. This will enable improving the use and protection of natural resources, unifying the process of manufacturing building materials and structures and creating favorable conditions for ecologic recovery of environmental management systems in the construction industry. Issues related to the application of innovative methods in the construction and to the use of resources are represented in works of the authors: Voronin A.O. [1], Gordienko I.I [2]., Grechko V.V. [3],

\footnotetext{
${ }^{*}$ Corresponding author: elenvoskr@mail.ru
} 
Andreev S.V. [4], Tkacheva I.V. [5], Voskresenskaya E. [6]. The authors of the article also payed attention to certain problems of the legal and organizational and economic mechanism of rational nature management and environmental protection in construction [7- 9]. However, the study of innovative approaches to the organization of the use of natural resources and to formation of effective environmental protection activity is at an insufficient level. This situation implies new aims and tasks for solving complex issues of rational nature management in construction. The aim of the study is to develop methodological bases for the legal regulation of the organizational and economic mechanism of nature management and environmental protection in the construction sector.

\section{Materials and Methods}

Ecological and economic relations are characterized by high complexity, which means that they cannot be directly perceived and changed. The expansion and deepening in learning the processes of productive force development has formed a new direction in the use of natural resources and nature management, which reflects the content of environmental and economic relations in the process of rational use, reproduction of natural resources and environmental protection in all areas including the construction sector. In this regard, the process of nature management is closely connected to the economy of construction and forms the initial information on the need of using natural resources in solving the problems of the effectiveness of the development of the construction complex. The accrual of new objectives of rational natural resource usage and environmental protection in the construction industry is caused by considerable need for management practices in this area.

The structure of rational nature management in the construction complex should include the process of planning, extraction and use of natural resources, the development of an integrated environmental protection system, the development of environmentally friendly building materials and structures, the reduction of surface and groundwater pollution and the organization on this basis of effective environmental activities in the construction sector. At the same time, the basis for planning an integrated system of effective environmental management in all production areas is the aggregate anthropogenic load in conjunction with innovative methods to prevent negative consequences. The maintaining of construction production, taking into account the provision of its environmental safety is a prerequisite for the formation and development of rational nature management in this area. In this regard, it is important to consider the specifics of the use of natural resources in terms of their rational use in the construction sector, as well as the features of landscape territories, which basically correspond to market conditions. The development of construction production is associated with the use of various raw materials and their processing, connected with the growth of scientific and technological progress and increase in construction volumes. Such increase inevitably leads to ecological balance disruption in the environment. These negative consequences of the construction industry should be eliminated by developing and implementing a set of environmental measures based on innovative approaches, as well as on advanced technologies for their implementation.

\section{Results}

All types of anthropogenic loads on the environment in the construction sector can be classified according to the following ecological features:

- allocation of land for construction sites, changing the environment, changing the animal and vegetable communities, changing the visual dominants that determine the characteristic appearance of the landscape; 
- pollution of the environment with construction waste and associated negative processes: an increase in the radiation background, noise and vibration processes, violation of the temperature regime and other visual dominants, alien to the natural landscape.

The construction industry is one of the most material-intensive and energy-intensive branches of the national economy. It accounts for about $50 \%$ of the consumption of energy produced by mankind and $60 \%$ of material resources. The production of building materials consumes the waste of industrial production to the greatest extent than other industries. One of the negative manifestations of building technogenesis is pollution of the natural environment, including air. Negatively influencing factor are energy emissions (noise, infrasound, vibration, ionizing radiation, etc.). The work of the construction industry enterprises is accompanied by the formation of a huge volume of sewage and solid waste.

During construction, ecologically negative processes that affect all types of natural resources (land, water, air) are manifested to the greatest extent.

\section{Discussion}

In order to prevent the ecological balance disrupting in the future, it is necessary to form the production potential of fixed assets in extreme natural conditions, which implies certain requirements to the directions of scientific and technological progress. These requirements are:

1. System approach to planning and forecasting investment and construction programs for the purpose of integrated development and protection of the region's natural resources;

2. Elaboration of effective solutions for the development and preparation of new territories, the establishment of foundations on permafrost soils of a special category;

3. Increased level of automation of the processes of introducing new technologies in the construction industry;

4. Improvement of operational activities aimed at increasing the return on assets;

5. Introduction of a continuous cycle of construction and operation of machinery and mechanisms under extreme conditions.

The implementation of the STP improvements mentioned above will increase the intensification and efficiency of development of territories having specific natural conditions, improve the use of fixed assets and increase their return on capital, accelerate the solution of important social problems of their economic development and meet the construction needs in raw materials. The improvement of environmental legislation in the rationalization of environmental management is the factor of the same import. Negative impact on the ecological state is provided by construction and installation works when erecting underground parts of buildings. Table 1 shows the indicators characterizing the impact of economic activities on the environment and natural resources in 2013-2016 [9].

Table 1. The main indicators characterizing the impact of economic activity on the environment and natural resources.

\begin{tabular}{|l|r|r|r|r|}
\hline Types of economic activity & 2013 & 2014 & 2015 & 2016 \\
\hline $\begin{array}{l}\text { Water abstraction from natural } \\
\text { water bodies for use, billion m3 }\end{array}$ & 61.0 & 63.2 & 60.8 & 61.4 \\
\hline $\begin{array}{l}\text { Discharge of contaminated } \\
\text { sewage, bn m3 }\end{array}$ & 15.2 & 14.8 & 14.4 & 14.5 \\
\hline $\begin{array}{l}\text { Emissions of pollutants into the } \\
\text { atmosphere, mln tons }\end{array}$ & 32.0 & 30.3 & 31.3 & 31.6 \\
\hline $\begin{array}{l}\text { Production and consumption } \\
\text { waste generation, mln tons }\end{array}$ & 5153 & 5168 & 5060 & 5441 \\
\hline
\end{tabular}

Table 2 shows the statistics on environmental expenditures in Russia for 2012-2015. 
Table 2. Costs for environmental protection in the area of environmental protection activity, mln. rub.

\begin{tabular}{|l|r|r|r|r|}
\hline Types of economic activity & 2012 & 2013 & 2014 & 2015 \\
\hline $\begin{array}{l}\text { The volume of environmental } \\
\text { protection costs in total, } \\
\text { including in the areas of } \\
\text { environmental protection: }\end{array}$ & 445817 & 479384 & 535863 & 562449 \\
\hline $\begin{array}{l}\text { Protection of atmospheric air and } \\
\text { prevention of climate change } \\
\text { collection and treatment of waste } \\
\text { water }\end{array}$ & 89236 & 93251 & 122421 & 103950 \\
\hline waste management & 186445 & 204351 & 223439 & 234112 \\
\hline $\begin{array}{l}\text { protection and rehabilitation of } \\
\text { lands, surface and groundwater }\end{array}$ & 41022 & 51612 & 60885 & 68483 \\
\hline & 36498 & 33486 & 36105 & 37952 \\
\hline $\begin{array}{l}\text { biodiversity conservation and } \\
\text { other }\end{array}$ & 28091 & 28082 & 34489 & 45893 \\
\hline $\begin{array}{l}\text { The volume of environmental } \\
\text { expenditures as a percentage of } \\
\text { GDP }\end{array}$ & & & & \\
\hline
\end{tabular}

Table 3 shows statistics on the area of disturbed, worked and reclaimed lands by types of use.

Table 3. Areas of disturbed, worked and reclaimed lands by types of use for 2013-2015, hectares.

\begin{tabular}{|c|c|c|c|}
\hline \multirow[t]{2}{*}{ Types of economic activity } & \multicolumn{2}{|c|}{ Lands disturbed for the year } & \multirow[t]{2}{*}{ Lands reclaimed } \\
\hline & Totally & $\begin{array}{r}\text { Therefrom } \\
\text { worked }\end{array}$ & \\
\hline $\begin{array}{l}\text { Totally } \\
2013 \\
2014 \\
2015 \\
\text { including: }\end{array}$ & $\begin{array}{l}137126 \\
130144 \\
136232\end{array}$ & $\begin{array}{l}81524 \\
85567 \\
97608\end{array}$ & $\begin{array}{l}74651 \\
70408 \\
86552\end{array}$ \\
\hline $\begin{array}{l}\text { when developing mineral deposits } \\
2013 \\
2014 \\
2015\end{array}$ & $\begin{array}{l}74206 \\
79475 \\
77676 \\
\end{array}$ & $\begin{array}{l}41368 \\
48545 \\
47894 \\
\end{array}$ & $\begin{array}{l}35505 \\
33977 \\
39906 \\
\end{array}$ \\
\hline $\begin{array}{l}\text { due to leakage during the transit of } \\
\text { oil, gas, oil refined products } \\
2013 \\
2014 \\
2015\end{array}$ & $\begin{array}{l}188 \\
418 \\
821\end{array}$ & $\begin{array}{l}132 \\
222 \\
382\end{array}$ & $\begin{array}{l}141 \\
271 \\
492 \\
\end{array}$ \\
\hline $\begin{array}{l}\text { During construction works } \\
2013 \\
2014 \\
2015\end{array}$ & $\begin{array}{l}44663 \\
40227 \\
39604\end{array}$ & $\begin{array}{l}28216 \\
29561 \\
33477\end{array}$ & $\begin{array}{l}28226 \\
28543 \\
29080\end{array}$ \\
\hline $\begin{array}{l}\text { During reclamation works } \\
2013 \\
2014 \\
2015\end{array}$ & $\begin{array}{r}256 \\
2182 \\
46\end{array}$ & $\begin{array}{r}213 \\
2136 \\
48\end{array}$ & $\begin{array}{r}205 \\
2224 \\
52\end{array}$ \\
\hline $\begin{array}{l}\text { During logging operations } \\
2013 \\
2014 \\
2015\end{array}$ & $\begin{array}{l}6283 \\
4018 \\
5740\end{array}$ & $\begin{array}{l}5043 \\
2365 \\
3206\end{array}$ & $\begin{array}{l}3519 \\
2285 \\
4807\end{array}$ \\
\hline
\end{tabular}




\begin{tabular}{|l|r|r|r|}
\hline During prospecting works & 7036 & 3748 & 3113 \\
2013 & 261 & 248 & 304 \\
2014 & 7133 & 8073 & 8450 \\
2015 & & & \\
\hline During placing industrial and solid & & & \\
household waste & 714 & 218 & 218 \\
2013 & 471 & 74 & 110 \\
2014 & 856 & 282 & 349 \\
2015 & & & \\
\hline During other works & 3780 & 2585 & 3725 \\
2013 & 3094 & 2416 & 2695 \\
2014 & 4357 & 4247 & 3418 \\
2015 & & & \\
\hline
\end{tabular}

In the modern construction complex, the occurrence of anthropogenic factors negatively impacts not only the territories, which are adjacent to construction sites, but also distal landscapes that directly interact with the ecological component of the environment as a whole. Currently, more than a fifth part of all emissions in Russia from stationary sources accounts for the share of enterprises that produce building materials, including dust-forming components.

Enterprises of the construction industry and construction complex have a significant negative impact on the sanitary and hygienic state of surface waters of water bodies, since the water resource is the most easily affected to anthropogenic impact on the natural environment. Construction production is a major consumer of water resources, which are used in the process of manufacturing materials, products and structures and in satisfying drinking and household needs. Water resources are used for cleaning technical and transportation equipment, heat supply system and for other needs. On this basis, the following types of impacts of construction projects on water resources can be identified:

- unregulated use of water resources, which can lead to shallowing or complete drainage of certain water bodies;

- pollution of surface water with construction waste;

- violation of seasonal use, regardless of the water regime of reservoirs provided for use in construction.

The construction industry has a negative impact not only on the environmental pollution of surface, but also groundwater. To increase the rational use of water resources in the construction industry, it is necessary:

- to introduce low-waste and non-waste technologies that provide sewage treatment;

- legislatively prescribe the conditions and procedure for the production of treatment measures for the construction of various facilities;

- implement monitoring activities to improve the quality of water resources used and generally the natural environment in the field of construction.

The load on the surrounding environment during the realization of the construction works often leads to the flushing and eroding of the soil cover, the formation of linear gullies, the destruction of vegetation cover.

\section{Conclusions}

Solving the problems of environmental protection and nature management demands the establishment of strict control over compliance with land legislation, elimination of violations of the document compilation for the land allotment for construction sites, involvement into construction of land plots that are not suitable for agricultural production. 
In accordance with the provisions of the Federal Law of the Russian Federation "On Environmental Protection", a set of measures for environmental assessment is conducted concerning the planned economic activities (including construction), which may have not only direct but also indirect impact on the environment. At the same time, the normative acts that have been in effect in recent years are not properly implemented, since they lack economic and financial justification for their implementation. This is the main aim of the formation of rational nature management on the basis of ubiquitous supplying this process with raw materials and technical resources, which would in general enable increasing the efficiency of all environmental activities in construction.

When elaborating all alternative options for pre-design and design documentation, early detection, analysis, assessment and recording of possible negative impacts of the proposed construction sites on the environment should be provided.

In construction sector, the EIA (Environmental Impact Assessment) materials should contain:

- description of the type of planned construction activity and its objectives;

- characteristics of individual components of the natural environment that can be significantly affected by the planned construction activity or its alternatives;

- predictive assessment of the impact degree of the planned construction activity and its alternatives;

- description of recommended measures that can minimize the negative impact of construction projects on the environment;

- suggestions of alternatives to the planned construction activities (if necessary), including the option to refuse construction.

The authors consider that the aims of the construction ecology include:

- production of optimization works with architectural and planning solutions for locating urban development facilities while ensuring favorable environmental conditions;

- development of forecast and assessment actions to reduce the negative consequences in the construction industry;

- introduction of waste-free or low-waste technologies in the manufacture of building materials and structures that ensure the development of environmentally sustainable areas;

- use of high town-planning technologies that have a favorable impact on natural resources;

- Conducting environmental monitoring, ensuring the adoption of decisions on the formation of environmentally friendly territories.

\section{References}

1. A.O. Voronin, Predostavlenie zemel' naselennykh punktov dlya stroitel'stva khozyaystvennykh (2009)

2. I.I. Gordienko, Pravovoe regulirovanie predostavleniya zemel'nykh uchastkov dlya stroitel'stva (2010)

3. V.V. Grechko, Pravovoe regulirovanie predostavleniya zemel'nykh uchastkov dlya zhilishchnogo stroitel'stva iz zemel', nakhodyashchikhsya $v$ gosudarstvennoy $i$ munitsipal'noy sobstvennosti (2013)

4. S.V. Andreev, Zemel'nyy pravoporyadok v oblasti gradostroitel'stva (2007)

5. I.V. Tkacheva, Pravovoe regulirovanie predostavleniya dlya stroitel'stva zemel'nykh uchastkov v gorode Moskve (2008)

6. E. Voskresenskaya, V. Snetkov, A. Tebryaev, Z. Askarov, MATEC Web of Conferences 106, 08055 (2017) 
7. E. Voskresenskaya, L. Vorona-Slivinskaya, A. Loiko, Legal Support of Ecological Safety in Russia. Web of Scholar 6(24)-7, 32-37 (2018) doi: 10.31435/rsglobal_wos/12062018/5800

8. E. Voskresenskaya, L. Vorona-Slivinskaya, E3S Web of Conferences 33, 03052 (2018) https://doi.org/10.1051/e3sconf/20183303052

9. P. K. Sun, L. Vorona-Slivinskaya, E. Voskresenskaya, IOP Conference Series: Earth and Environmental Science 90 (2017) https://doi.org/10.1088/1755-1315/90/1/012073

10. Regiony Rossii, Sotsial'no-ekonomicheskie pokazatel R32 (2017) 